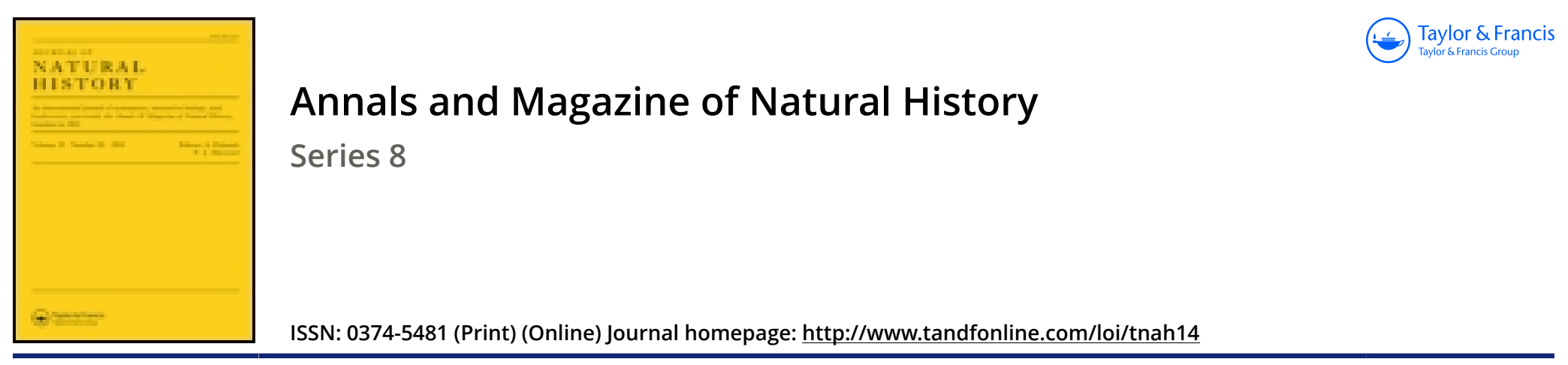

\title{
XXXIII.-The British Roe-deer (Capreolus capreolus thotti), a preliminary diagnosis
}

\section{Dr. Einar Lönnberg C.M.Z.S.}

To cite this article: Dr. Einar Lönnberg C.M.Z.S. (1910) XXXIII.-The British Roe-deer (Capreolus capreolus thotti), a preliminary diagnosis, Annals and Magazine of Natural History, 6:33, 297-298, DOI: $10.1080 / 00222931008692854$

To link to this article: http://dx.doi.org/10.1080/00222931008692854

Published online: 08 Sep 2009.

Submit your article to this journal $\sqsubset$

Џ Article views: 2

Q View related articles $\square$ 
the ventrals, its lower limb wider and boldly sinuous at its origin, the rest narrow and feebly sinuous. A large photophore behind and slightly below the eye, oceluded by skin Eave for a narrow slit. A row of very small photophores, hardly visible externally, below the middle line of the side from the head to the caudal peduncle; another row near the ventrum, trom the thoracic region t) the anus. Colour velvety black; looped band purplish grey; barbel grey.

Total length without caudal fin and lower jaw (in type) $172 \mathrm{~mm}$.

We are indebted to our friend Professor MacBride for sections of a part of the looped band. Preliminary examination shows a cord of apparently glandular tissue, oval in section, covered with a thin membrane and lying in a groove of the skin, of which the black pigment is continuel throughout the groove. We find nothing in the structure to sugg ist that the band is a lateral line, though its position suggests a derivation from that organ, which in its ordinary form is absent from both species of Grammatostomias. We have ascertained from the authorities of the U.S. National Museum and Dr. Brauer that the type of $G$. dentatus and the material of closely allied forms taken by the 'Valdivia' are sufficiently perfect to make it certain that none of them possessed any structure in the nature of the looped band, which appears to be a luminous organ.

XXXIII.-The British Roe-deer (Capreolus capreolus thotti), a preliminary Diagnosis. By Dr. EINAR LönNBERG, C.M.Z.S.\&.

A FEw years ago my friend Count Tage Thott mentioned to me that he had seen some British Roe-deer which appeared to him to be different to the Swedish which constitute the type of Linnæus's species.

During a sojourn in London this summer I had the opportunity of ascertaining the correctness of Count 'Thott's observation by studying, with the kind permission of Mr. Oldfield Thomas, the material of British Roo-deer in the British Museum Nat. Hist. I am thus able to give the following short preliminary diagnosis, and hope to have the opportunity in the near future to publish a more complete description accompanied by some figures.

The British Roe-deer, which appear's to be somewhat Ann. \& Mag. N. Ilist. Ser. 8. Vol, vi. 
smaller and to have smaller antlers, is a very much darker animal all over than the Swedish, and it has a more blackish face and blackish ears. As type for the new subspecies I propose no. 8.11.22.1 in Brit. Mus. Nat. Hist., from Aberfeldy. In winter pelage the whole face and the sides of the head are blackish. The nose is sprinkled with whitish tips to some hairs; especially on a spot above the rhinarium, these light-tipped hairs are more numerous, and the sides of the head grizzled with longer buffish tips to the hairs. On the forehead the black ground-colour dominates, but is somewhat sprinkled with buff tips. The ears are mixed black and buff-more black at the tips, more buff basally. The neck and the back are dark brown, the visible parts of the hair being blackish with rings of a rich buff, sometimes inclining to rufous. The basal, not visible, parts of the hair are dark grey, much darker than in Swedish specimens. The sides of the body are not quite so dark as the back, the groundcolour being somewhat paler and the rings paler buff. The throat behind the white chin-spot is buffish, lighter in the middle. The lower side of the nock is buffish grey, not coarsely sprinkled as in Swedish specimens. The lower side of the breast is grey, darker and less buffish than in Swedish specimens. The black nose-mark and the speculum as usual, although the latter seems to be smaller than in Swedish specimens. The fur all over the body is not so long nor so coarse as in Swedish specimens.

In summer pelage the British Roe-deer has a black patch on the forehead surrounded by rufous and somewhat sprinkled with the same colour. The ears have broad blackish margins and are otherwise mixed with buffish. The upper neck and back are very rich rufous, the sides of the body somewhat paler, and the lower parts still lighter; the throat behind the white chin-spot pale buff, the belly almost whitish.

XXXIV.-Description of the Indian Butterfy Parantirrhoa marshalli, W.-M. (female). By Lieut.-Colonel N. MANDERS, F.E.S.

THE male was described by Wood-Mason in 1880 from a male specimen captured by Mr. Harold Ferguson in the Ashamboo Hills in May. The female is not noticed by Bingham ('Butterflies of India,' vol. i. 1905), and a description would therefore appear to be necessary, as it is evidently unknown. 